\title{
FIRM-SPECIFIC CHARACTERISTICS AND THE TIMING OF FOREIGN DIRECT INVESTMENT PROJECTS
}

\author{
HORST RAFF \\ MICHAEL J. RYAN \\ CESIFO WORKING PAPER NO. 1874 \\ CATEgORY 7: TRAdE POLICY \\ DECEMBER 2006
}

An electronic version of the paper may be downloaded

- from the SSRN website:

- from the RePEc website:

www.SSRN.com

- from the CESifo website:

www.RePEc.org

www.CESifo-group.de 


\title{
FIRM-SPECIFIC CHARACTERISTICS AND THE TIMING OF FOREIGN DIRECT INVESTMENT PROJECTS
}

\begin{abstract}
This paper uses a proportional hazard model to study foreign direct investment by Japanese manufacturers in Europe between 1970 and 1994. We divide each firm's investment total into a sequence of individual investment decisions and analyze how firm-specific characteristics affect each decision. We find that total factor productivity is a significant determinant of a firm's initial and subsequent investments. Parent-firm size does not have a significant influence on the initial decision to invest. Large firms simply have more investments than smaller firms. Other firm-specific characteristics, such as the R\&D intensity, export share and keiretsu membership, also play a role in the investment process.
\end{abstract}

JEL Code: F23, L20.

Keywords: foreign direct investment, productivity, hazard model, Japan, keiretsu.

Horst Raff

Department of Economics

Christian-Albrechts-University Kiel

Olshausenstr. 40

24098 Kiel

Germany

raff@econ-theory.uni-kiel.de
Michael J. Ryan

Department of Economics

Western Michigan University

1903 W. Michigan Ave.

Kalamazoo, MI 49024

USA

michael.ryan@wmich.edu

November 2006

The authors would like to thank Pravin Trivedi, David Audretsch and seminar participants for their comments and suggestions. 


\section{Introduction}

Foreign direct investment (FDI) has replaced international trade as the main driving force behind the global integration of product markets. According to UNCTAD (2004), aggregate sales by foreign affiliates have exceeded world exports for more than two decades. If one looks at the firm level, the typical pattern behind this development has been that firms that used to supply foreign markets through exports from a production facility at home have established production plants in those markets to supply them locally. This raises a number of questions, including which kinds of firms will switch from exporting to FDI, at what point in time will they switch, and how many investments will they undertake. We address these questions using data on Japanese manufacturers' FDI into Europe during the period 1970 to 1994. In particular, we examine (i) how firm productivity, size and other firm-specific characteristics affect the likelihood and timing of a firm's first manufacturing project in Europe, and (ii) whether these same characteristics remain as FDI influences as the firm continues to invest.

The paper differs from previous studies of FDI in two ways. First, most of the existing FDI literature consists of proximity-concentration models that link the exportversus-FDI choice to country- and industry-level determinants, including factor endowments, market size, trade costs and economies of scale (see Markusen (2002) for a recent survey). The current paper is about firm-level influences on the choice of FDI and about heterogeneity in the investment behavior of firms, issues on which there has been comparatively little systematic research. ${ }^{1}$

Second, we track a firm's sequence of individual investment decisions, and are hence much better able than most previous papers to distinguish between those firmspecific characteristics that determine a firm's initial decision to invest and those influencing the firm's subsequent investments. Why this matters can best be illustrated using a hypothetical firm-level data set. Suppose there are four Japanese firms, as

\footnotetext{
${ }^{1}$ Since Hymer (1960) and Horst (1972), firm-level empirical studies have identified a firm's size as the key determinant of its propensity to undertake FDI. Swedenborg (1979), Blomström and Lipsey (1991), and Trevino and Daniels (1994) have found firm size as well as R\&D expenditures, export intensities, and previous investment experience all contribute to increased FDI likelihood. More recently, Helpman, Melitz and Yeaple (2004), Head and Ries (2003), Girma, Gorg, and Strobl (2004), and Raff, Ryan and Stähler (2005) have identified a firm's productivity as a determinant of the choice between exporting and FDI. See Greenaway and Kneller (2005) for a survey.
} 
illustrated in Table 1, each with a different number of manufacturing investments in Europe between 1970 and 1994. Firm 1, for example, established a first affiliate early in the sample period, a second affiliate toward the middle of the period and then, in short order, two more affiliates (we do not consider subsequent investments into the same affiliate). Firm 2 set up only a single affiliate in the middle of the period, firm 3 established two affiliates, and firm 4 has three affiliates.

Table 1: Hypothetical Sample

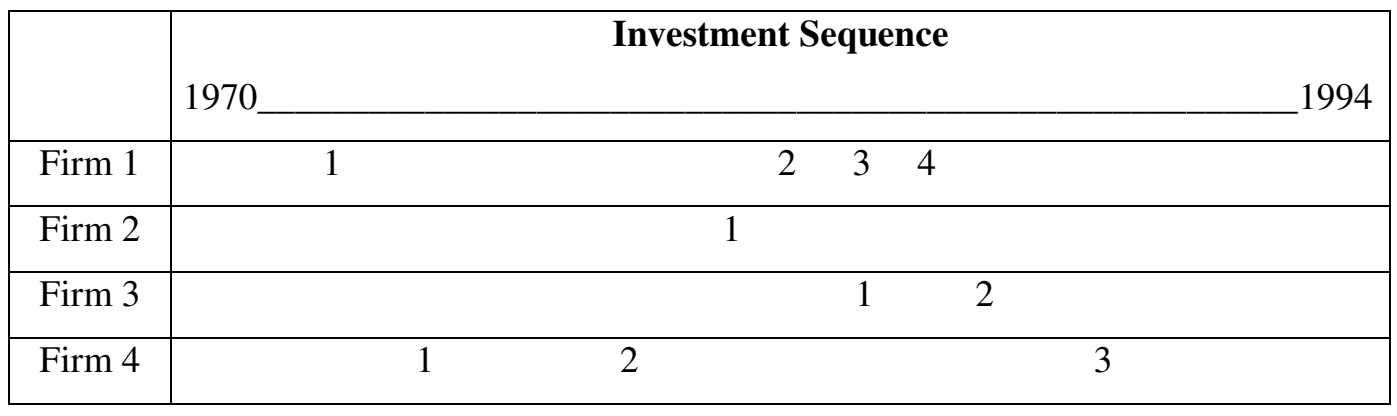

Previous studies typically follow one of two approaches: (i) they pool all the investments for all the firms - so that there are 10 separate investments in total - and then examine how firm productivity, size and other characteristics influence the average investment decision; or (ii) they pool the investments of each firm and investigate how firm characteristics affect a firm's total number of investments (or the total amount of capital invested). Both approaches ignore information that is potentially very valuable in understanding FDI decisions.

First, pooling the data implies that one cannot distinguish between how firm characteristics affect the likelihood of making a first investment and how they affect the likelihood of subsequent investments (and thus the investment total). This may be a problem, for instance, when it comes to separating the effects of firm size (as measured by assets or sales) and productivity on the likelihood of making an investment. In any given market, the most productive firms also tend to have the largest output or market share; hence productivity and size are positively correlated. But size may also be a function of other factors, such as technological and informational complementarities, or economies of scope across product lines (see, for instance, Lindbeck and Snower, 2003). Hence firm size may also manifest itself in the number of products or product lines a firm has. Studies using pooled data may erroneously find that firm size matters, when all they 
pick up is that bigger parent firms have more affiliates, where each produces perhaps a different product.

Second, these studies disregard the inter-temporal nature of investment decisions. For instance, they do not take into account the option value of waiting to make an irreversible investment until the firm has learned more about demand and other hostcountry factors, or that firms may learn from earlier investments about the likely profitability of subsequent investments.

Third, they fail to take into account possible interdependencies between the investments of a given firm, since they effectively treat each firm as a singleproduct/single-plant firm. But like probably most multinational firms, the ones in our Japanese sample typically have multiple product lines (say automobiles, motorcycles and trucks) and most likely multiple products within each line. Some products or product lines may be substitutes, others may be complements, and this should be reflected in the investment decision.

In the current paper we separate a firm's investment total into a sequence of individual investment decisions, and analyze how firm-specific characteristics affect the investment likelihood at each stage. In particular, we distinguish between those firmspecific characteristics that determine a firm's initial decision to invest and those influencing the firm's subsequent investments. We avoid sampling bias by including both investing and non-investing firms in our sample. Empirical analysis is through the proportional hazard model that focuses on the duration between events (investments), thus allowing us to focus on investment timing. The hazard model's temporal dimension allows a firm's time-varying characteristics (e.g, productivity, size) to be continually updated throughout the investment sequence. This will lead to increased estimation efficiency as compared to the (typically employed) empirical tests that use a single data point for each variable included in their analysis, ${ }^{2}$ while also allowing each individual stage of the investment sequence to be examined separately.

Estimation results indicate that total factor productivity is a significant determinant of FDI at each stage of the investment process: the more productive a firm is the more likely it is to undertake an investment and the shorter is the duration between

\footnotetext{
${ }^{2}$ See Cameron and Trivedi (1998), page 8.
} 
investments. Firm size, by contrast, only matters for later stages, which simply means that large firms on average undertake more investment projects. These results are related in two ways to the previous literature. ${ }^{3}$ First, they shed light on the "threshold effect" found in previous studies. Blomström and Lipsey (1991), for instance, find that only firms exceeding a certain critical size engage in FDI, whereas studies along the line of Helpman, Melitz and Yeaple (2004) suggest that only firms exceeding a critical level of productivity choose FDI. Specifically, we find such an effect only for productivity. Second, Blomström and Lipsey (1991) argue that firm size has no effect on the extent of a firm's investment, whereas papers on the role of productivity implicitly treat firms as single-product firms and thus have nothing at all to say about the extent of a firm's investment. Our paper shows that larger and more productive firms tend to have more investments.

We also obtain different results than earlier papers when we consider the effect of keiretsu membership on FDI. Specifically we find that keiretsu membership only significantly impacts investment at later investment stages. This means that keiretsu firms are not more likely than other firms to have a foreign manufacturing affiliate, they simply have more of them on average. By contrast, most of the theoretical and empirical papers in this literature find that keiretsu membership raises the likelihood of investment. ${ }^{4}$ Like in the case of firm size, the difference between our results and those of previous papers may be explained by the fact that we do not pool the FDI data: if we do pool that data, we arrive at the same conclusion as previous papers, namely that productivity, size and keiretsu membership all matter for the FDI decision.

This paper continues as follows. In Section 2 we present the theoretical framework, including our own model and a discussion of related theory papers. Section 3 contains the predictions. Section 4 describes the FDI data and the choice of control variables. Section 5 provides the empirical models, and Section 6 the estimation results. Section 7 concludes. The Appendix contains proofs and data sources.

\footnotetext{
${ }^{3}$ In addition to the papers already cited above, one should mention Chang and Rosenzweig (2001) who find that firm specific determinants of the entry-mode choice (wholly owned vs. joint venture) change over the investment sequence. Drake and Caves (1992) examine how the determinants of aggregate FDI flows change over time.

${ }^{4}$ For example, see recent empirical studies by Belderbos and Sleuwaegen (1996), Head, Ries, and Swenson (1999), and Blonigen, Ellis, and Fausten (2005).
} 


\section{Theoretical Framework}

In this section we set up a model of a multi-product, multi-plant firm that exports various goods to a host country and has to decide whether and at what time to switch to supplying a good locally by setting up a production facility in the foreign country. Various aspects of this decision problem have already been examined elsewhere. In Rob and Vettas (2003), for example, a single-product firm faces growing but uncertain demand in the foreign country and has to decide whether and at what time to invest abroad to install production capacity. Building on Dixit and Pindyck's (1994) model of irreversible investment under uncertainty, they show that demand uncertainty tends to delay FDI. Horstmann and Markusen (1987) have a model, again of a single-product firm, in which demand is growing at a fixed rate but the firm faces potential entry from local rivals. In this situation, the firm tends to invest earlier than indicated by pure cost considerations in order to deter entry. Baldwin and Ottaviano (2001), on the other hand, examine the exporting-versus-FDI decision from the point of view of a multi-product firm, but do so in a static framework. They show that multi-product firms have an additional incentive to locate production abroad, namely to reduce intra-firm competition between their products, the so-called cannibalization effect.

The Rob and Vettas paper yields clear predictions about the effect of demand uncertainty that we can use almost directly for our empirical analysis. Since uncertainty about demand (and other relevant host country parameters) tends to delay FDI and since a firm's estimates of these parameters are likely to improve as it gains investment experience, we would expect later investments, ceteris paribus, to be made more quickly than a first investment. We can test this prediction directly using a Kaplan-Meier test; more on this later. The Horstmann/Markusen and Baldwin/Ottaviano papers do not lead directly to testable predictions, because they are too restrictive in their assumptions. For instance, we can only observe rivals that have already entered the market but not potential rivals as in the Horstmann/Markusen paper. The Baldwin/Ottaviano paper only has two firms with two products each, and assumes that each product is produced in only one location - home or foreign. Nevertheless, inter- and intra-firm competition would appear to be important influences for a multi-product firm's FDI decision, and we hence 
take these two models as a starting point for our own theoretical framework to which we turn next.

We consider a firm based in the home country $(h)$ that manufactures differentiated goods in the production facilities that it has established there. We refer to this firm as firm $h$. It sells these goods at home and initially also exports them to the foreign country (f). Foreign demand grows at an exogenously given rate, and the firm has to decide whether and at what time to switch from exporting a good to producing it locally in the foreign country. The direct trade-off between exporting and FDI is the usual proximityconcentration trade-off: the firm saves transportation costs but incurs a sunk cost of setting up a new plant. We want to know how this trade-off and therefore the timing of investment projects is affected by (i) the firm's productivity, (ii) the number of goods it produces, (iii) the number of investments it has already undertaken, (iv) the degree of substitutability/complementarity among its products, and (v) the number of local competitors, i.e., market concentration.

To focus attention on firm $h$ 's investment decision, we assume that the markets in $h$ and $f$ are segmented, i.e., that there is no consumer arbitrage, and we let marginal production costs be constant. This implies that all FDI decisions are determined solely by the market equilibrium in country $f$. Firm $h$ produces $n$ goods, and sells quantities $x_{1}, \ldots, x_{n}$ in country $f$. The foreign market is also served by $m$ foreign rivals. We think of these rivals as being "small" firms, where each produces only a single good for the local market. We denote their outputs by $y_{1}, \ldots, y_{m}$. The number of identical foreign consumers at time $t$ is denoted by $N(t)$. Consumers base their demand for a good $i$ at time $t$ only on the price at $t, p_{i}(t)$. Assuming quadratic, quasi-linear preferences, the inverse demand at time $t$ for a good $i$ produced by firm $h$ is:

$$
p_{i}(t)=a-\frac{b}{N(t)}\left(x_{i}(t)+d \sum_{j \neq i} x_{j}(t)+e \sum_{k=1}^{m} y_{k}(t)\right),
$$

where $a>0, b>0, d$ and $e$ are time-invariant demand parameters. Parameter $d$ measures the degree of substitutability between firm $h$ 's products. If $d=1$, they are perfect substitutes; if $0<d<1$, they are imperfect substitutes; if $d=0$, demands are independent of each other; and if $d<0$, they are complements. Parameter $e$ measures the degree of substitutability between firm $h$ 's products and those of its rivals. We assume that the local 
firms' products are imperfect substitutes for those of firm $h$, i.e., $0<e<1$, but perfect substitutes for each other. The demand for a good $l$ produced by a local firm hence is:

$$
p_{l}(t)=a-\frac{b}{N(t)}\left(\sum_{k=1}^{m} y_{k}(t)+e \sum_{i=1}^{n} x_{i}(t)\right)
$$

When producing good $i$ in country $j=h, f$, firm $h$ incurs a marginal cost of $c_{i j}=w_{j}-\theta_{i}$, where $w_{j}$ denotes the country- $j$ wage rate and $\theta_{i}$ is a productivity parameter specific to good $i$. On each unit that firm $h$ exports to country $f$ it incurs shipping costs of $s$. We assume that the sunk cost of building a plant in the foreign country is $G$; this cost has to be incurred for each product. The local firms in country $f$ have a marginal cost of $w_{f}$.

Firms maximize the present value of their profits and are able to borrow at a constant rate $r$ to cover sunk costs. They engage in Cournot competition. We assume that at time $t=0$ cost and demand conditions are such that firm $h$ can profitably export all $n$ goods to the foreign market in equilibrium; demand is too small to support a subsidiary in country $f$. Over time, the number of consumers in $f$ and hence demand grows at a fixed rate. We see this assumption as a convenient shortcut to represent the more realistic scenario where demand increases come in spurts due to economic growth in Europe and the process of European integration.

\section{Predictions}

In this section, we characterize the investment strategies predicted by the model; firstorder conditions and formal proofs of the results are provided in Appendix I. Two preliminary results help us in deriving the predictions. First, for a given investment strategy, per-capita output and profits in Cournot equilibrium are independent of $t$. This is simply a consequence of three assumptions, namely that consumers base their decision on current prices, that demand is linear, and that the marginal cost is constant.

Second, if $w_{f}<c_{i h}+s$, then providing any given product $i$ through FDI yields firm $h$ a bigger profit, gross of the sunk cost of investment, than if it exported the product. This is due to the direct effect of having a lower variable cost and to the additional, strategic effect of gaining market share vis-à-vis local competitors. 
Together, these preliminary results imply that as the market grows over time firm $h$ will switch from exporting to FDI. More precisely, there exists a time $t_{l}$ at which the firm will switch to FDI in one good, since demand has grown large enough to compensate for the sunk cost associated with FDI. There also exists a time $t_{2}>t_{l}$ at which the firm will undertake a second investment, and so on.

We can now examine the influence of the time-invariant parameters on $t_{1}$ and $t_{2}$. The impact of country- and industry-specific variables is the same as in the standard proximity-concentration models. An increase in per-capita demand makes it more attractive to save transportation costs by engaging in FDI. Higher home relative to foreign wages, higher transportation costs and lower sunk costs of establishing a subsidiary also make FDI more profitable and hence reduce the time to investment. The number of foreign competitors, i.e., industry concentration, has an ambiguous effect. ${ }^{5}$

Firm-specific characteristics have the following effects. The greater is firm $h$ 's productivity, the bigger is the firm's market share and hence the more profitable is FDI and the shorter is the time to investment at each stage. The size of a firm in our model also depends on the number of goods it produces. This number has an ambiguous effect on the FDI decision, since the effect depends on the degree of substitutability or complementarity between goods. However, we can prove that if firm $h$ 's goods are imperfect substitutes, $t_{2}$ will be delayed due to the cannibalization effect. In particular, Suppose that $1>d>e>0$ so that firm $h$ 's products are imperfect substitutes, but better substitutes for each other than for the goods produced by local firms. Then, ceteris paribus, the time to the first investment is shorter than the time between the first and second investment.

\section{Data and Descriptive Statistics}

Our sample consists of the investments of 286 Japanese manufacturing firms. ${ }^{6}$ Inclusion into the sample was dependent upon meeting the following criteria: availability of firm-

\footnotetext{
${ }^{5}$ If all products were homogeneous and marginal costs were identical across firms, the effect of a greater number of foreign firms clearly would be to reduce the attractiveness of FDI. The ambiguity hence comes from the different degrees of substitutability/complementarity between goods and cost heterogeneity. ${ }^{6}$ See the Appendix II for details on data collection.
} 
specific data for the entire sample period (1970-1994), ${ }^{7}$ and for the firm's entire European manufacturing FDI to occur after 1969. The choice of this time period (197094) follows the Japanese government's initial deregulation of outward Japanese FDI in 1969. ${ }^{8}$ This time period also allows us to avoid the impact of the Asian financial crisis on outward FDI as well as the number of mergers/acquisition between Japanese firms in the late 1990s that would have significantly decreased the number of firms in the sample.

Once selected, investments in which the firm's shareholding stake is below $10 \%$ were eliminated from the firm's investment history. Of the 286 firms, each of which is listed on one of the Japanese stock exchanges, 176 firms established manufacturing affiliates in Europe, 103 had only non-manufacturing FDI, and 7 firms did not establish any European affiliate during this period. 184 firms were keiretsu members.

The sample contains a total of 372 manufacturing investments with 269 (72\%) of these investments made by keiretsu members. While the average date of initial manufacturing investment is earlier for keiretsu members (1983) than for non-members (1985), pre-1986 manufacturing investments as a percentage of a firm's investment total does not vary significantly according to keiretsu affiliation. Also, 57\% of all Japanese MNEs that ultimately invested in Europe by 1994 had already done so by 1985 , indicating that much of the Japanese investment into Europe between 1985-1994 was from experienced investors and not from firms new to the European market. Finally, keiretsu membership does appear to affect the number of investments, as members established on average 2.2 affiliates, slightly more than the 1.79 affiliates for nonmembers.

There are several methods to examine the duration between investments. There is an average duration of 4.5 for the establishment of a second affiliate, and 4 years for the establishment of a third, if all (including right-censored) durations are considered. ${ }^{9}$ For the same investment spells, the average duration rises to 5.2 (4.2) years if only those

\footnotetext{
${ }^{7}$ Hazard models are quite data intensive as they require data from each period (year) in the sample, in contrast to other typically used models (e.g., logit, probit) that require just a single data point for each observation, whether it be contemporaneous or lagged data, or an average across the sample period. Thus, only firms with complete data are included in our sample.

${ }^{8}$ Pre-1970 investment was quite limited, in part by the 1949 Foreign Exchange and Foreign Trade Control Law that essentially required Japanese government approval of all foreign direct investment until deregulation began in 1969. See Mason (1994) for more details. By 1994, investment into European manufacturing affiliates by the sample firms had fallen to 1973-levels.

${ }^{9}$ While certainly possible, our dataset includes no firms that simultaneously establish multiple affiliates.
} 
durations between established affiliates is considered; the rise is a result of the large fraction of single- and double-affiliate investors that invested late in the sample, creating numerous short (right-censored) second and third duration spells. If we account for the year of the firm's initial investment, we find that duration spells have fallen since the 1970s; for instance, the average duration between first-second investment and secondthird investments fell from 7.9 (5.9) years for firms initially investing between 1970-1974 to 3.0 (1.5) for those investors initially entering between 1985-1989. While this does suggest a "catch-up" by late-investing firms, we are most concerned with the general result (as illustrated in the Kaplan-Meier plots) that subsequent investments, regardless of duration measure, occur more rapidly than the previous investments.

Our model suggests that we should include two categories of explanatory variables: firm-specific characteristics, and country- and industry-specific controls. Here is how we proxy for them.

\subsection{Firm-Specific Characteristics}

According to the model, a firm's productivity and size play an important role in its investment strategy. Data availability allows us to measure a firm's total factor productivity (TFP) via the Levinsohn-Petrin (2003) method. Our model suggests that the greater is the firm's productivity, the shorter is the time to investment at each stage.

A firm’s total assets (in billions of 1993¥) are included as a measure of firm size (Size). The data is lagged by one year to eliminate possible endogeneity and to account for the potential time lag between the investment decision and the actual investment that shows up in our database. Size is positively correlated with $T F P$, as indicated by the model; but the correlation is only moderate: 0.261 (see Table 2). An alternative measure of firm size is the parent employment levels (Employ). This measure is highly correlated with Size (correlation coefficient: 0.654), and we hence use it only for robustness checks. 
Table 2: Correlation between major firm-level variables

\begin{tabular}{|l|l|l|l|l|l|l|l|}
\hline & TFP & Size & Export\% & R\&D & Keiretsu & HHI & Employ \\
\hline TFP & 1.000 & & & & & & \\
\hline Size & 0.261 & 1.000 & & & & & \\
\hline Export\% & 0.258 & 0.173 & 1.000 & & & & \\
\hline R\&D & 0.274 & 0.225 & 0.216 & 1.000 & & & \\
\hline Keiretsu & 0.254 & 0.204 & 0.174 & 0.156 & 1.000 & & \\
\hline HHI & 0.236 & 0.345 & 0.011 & 0.055 & 0.152 & 1.000 & \\
\hline Employ & 0.267 & 0.654 & 0.185 & 0.232 & 0.215 & 0.015 & 1.000 \\
\hline
\end{tabular}

A firm's size also can also be measured through the range of products it produces. While the data for the Japanese firms that comprise our sample does not indicate an exact number of product lines and we do not know the degree of complementarity among these lines, we are able to determine the percentage of sales disaggregated by the firm's major business lines or specific corporate branches. In most cases, this information is available at the 2- or 3-digit SIC level. We use this sales data to create a firm-specific HirschmannHerfindahl Index $(H H I)$, calculated as the sum of the squared sales percentages for each business line listed for the firm by the dataset. The index values range from 0 to 10,000 , with larger values indicating a less diversified corporation in terms of its sales breakdown. Note that the $H H I$ is positively, but moderately correlated with both Size and TFP. No a priori prediction can be made on the HHI index's effect on FDI, given the unknown degree of complementarity between product lines.

In addition to the HHI index, we also evaluate possible cannibalization or complementarity between products by identifying the affiliate's main business line. We create the variable Diversification to measure the degree of diversification in the parent's investment strategy. For each affiliate established by a Japanese parent, Diversification takes the value of 1 if it is established in an industry different from those previously established, and 0 if the affiliate is in the same industry as a previously established affiliate. For the first manufacturing affiliate established by each firm, a 1 is given if the affiliate's main business line differs from the parent's core business line, and 0 if it is the same. Determination of the affiliate's main business line occurs at the 3-digit SIC level.

In the model section, we assume for simplicity that all of the firm's products are initially exported. Obviously this is not the case in practice, where the firm will export only those goods that it can manufacture at a high enough level of productivity to be able to compete with local producers of substitute goods and to justify the transportation costs 
(and possible additional fixed exporting costs that we do not model). Hence the firm's annual export share (Exprt), computed as the ratio of export sales to total sales in a given fiscal year, should also be an indicator of the firm's productivity and competitiveness. ${ }^{10}$ Exprt and TFP are indeed positively correlated as indicated by Table 2. Annual R\&D intensity $(R \& D)$ is measured by the ratio of $R \& D$ expenditures to total sales for the fiscal year. It constitutes another indicator of the firm's productivity and ability to compete with local rivals. ${ }^{11}$ Exprt and $R \& D$ are lagged by one year to account for possible endogeneity. Both Exprt and $R \& D$ should have a positive influence on the likelihood of FDI at each point in time.

Next, we also want to account for the obvious fact - not dealt with in the model that a firm may gain knowledge or experience from investment projects that is useful for subsequent projects. For each firm, the number of previously established European manufacturing affiliates (PrevManufInvst) is determined at the time of each investment. Use of this PrevManufInvest alone limits investment history heterogeneity to differences in previous investment totals. As a result, we also include the size of the firm's European distribution and service network (PrevNonManufInvst) that is determined by the count of all previously established non-manufacturing European affiliates at the time each manufacturing affiliate is established. The establishment of a distribution network typically precedes investment into manufacturing. While this may lengthen the time to a manufacturing investment, e.g., if managerial or financial resources are scarce, having an established distribution network may also be helpful in establishing a manufacturing affiliate, e.g., because it provides information and contacts with customers. We also include the length of the firm's previous manufacturing investment spell (PrevDuration) to control for previous investment timing. This variable allows for firms with similar investment totals to have different previous investment experiences based on when the previous investments occurred.

\footnotetext{
${ }^{10}$ Note that actual exports to Europe are not available at the firm level.

${ }^{11}$ Firms' 1986 R\&D expenditures are used for the years prior to 1986 when R\&D expenditure data was not available. See Padmanahban and Cho (1996).
} 


\subsection{Additional Controls}

We control for industry-specific influences using industry affiliation dummies created for each investing parent at its 2-digit SIC code. With regard to country-level influences note that in our empirical analysis we treat Europe as a single country, controlling for changes in country-level influences over time with a time dummy and by including European GDP (EuropeanGDP), measured in constant US dollars. ${ }^{12}$

Since we are dealing with Japanese FDI, we have to control for the existence of "horizontal" and "vertical" keiretsu. Membership in such a keiretsu is believed to increase FDI likelihood as compared to non-members and non-Japanese MNEs with similar firm-specific characteristics. Keiretsu affiliation and the firm's inclination toward its particular keiretsu are located in various editions of Dodwell Marketing's Industrial Groupings in Japan. ${ }^{13}$ For the purposes of this study, the dummy variable KeiretsuMember takes a value of 1 if the firm is keiretsu member, with the dummy variables HorizontalKeiretsuMember and VerticalKeiretsuMember taking the value 1 if the firm is affiliated with a horizontal or vertical keiretsu, respectively. Note that we do not use all three variables in the same regression; rather we will use KeiretsuMember in most regressions, and on occasion use the HorizontalKeiretsuMemberl VerticalKeiretsuMember pair. All three variables are expected to have a positive affect on a firm's propensity for investment. In addition, we will interact the membership dummy variables with Size and TFP to measure size and TFP differentials between keiretsu members and non-members.

Finally, we control for three measures of the firm's financial health: GrossRevenue, calculated as the firm's gross revenue divided by its total assets; InterestBurden, calculated as its interest payments divided by gross revenue; and CashFlow, which is a measure of its post-tax profits plus depreciation divided by gross revenue. A priori, we expect GrossRevenue and CashFlow to positively influence investment likelihood, while a higher InterestBurden should negatively affect investment likelihood.

\footnotetext{
${ }^{12}$ Since Japanese affiliates in Europe often serve the entire European market, we do not consider the question of where in Europe a firm may chose to invest. To address this question properly we would have to estimate multiple hazard models, one for each potential host country.

${ }^{13}$ The Dodwell keiretsu classification system is chosen over other systems because it applies the most rigid standards to group affiliation. See Belderbos and Sleuwaegen, note 10 (1996).
} 


\section{Econometric Estimation}

\subsection{Kaplan-Meier Estimation}

The first prediction we want to test is that uncertainty about demand (and other relevant host-country parameters) tends to delay FDI and that, as a firm's estimates of these parameters improve with experience, later investments are made more quickly than the first investment (see Rob and Vettas, 2003). We can test this prediction using a KaplanMeier test. To do so, note that in a repeated investment model, an observation is defined as a distinct time spell until an investment occurs. For firms with multiple investments, individual spells are recorded for each investment. For example, a firm establishing two manufacturing affiliates in 1982 and 1991, respectively, generates three spells, the third of which (1992-1994) is right-censored. A single right-censored spell of 25 years is created for firms without a manufacturing affiliate. Left-censoring is not a consideration, as none of the sample firms established a European manufacturing affiliate prior to 1970.

Following Kiefer (1988), let $\mathrm{T}$ be a random variable that measures the duration between spells with the probability distribution $F(t)=\operatorname{Pr}(T<t)$ and corresponding density function $f(t)$. The survivor function, or the probability that the duration between investments survives beyond time $t$ is defined as $S(t)=1-F(t)=\operatorname{Pr}(T \geq t)$. In addition, the duration between investments can be characterized by the hazard function $\lambda(t)=f(t) / S(t)$. $\lambda(t)$, the conditional probability that investment occurs shortly after $t$, given that investment has not taken place at time $t$, is precisely defined as

$$
\lambda(\mathrm{t})=\lim _{h \rightarrow 0} \operatorname{Pr}(\mathrm{t} \leq \mathrm{T} \leq \mathrm{t}+\mathrm{h} \mid \mathrm{T} \geq \mathrm{t}) / \mathrm{h}
$$

The shape of $\lambda(t)$ indicates duration dependence. Positive duration dependence, $d \lambda(t) / d t>0$, indicates that the probability that an investment will occur increases with spell length, while $d \lambda(t) / d t<0$ indicates negative duration dependence.

\section{[Insert Figure 1 here]}

Figure 1 plots the Kaplan-Meier hazard function estimates of (3) by position in the investment sequence, where each curve corresponds to an individual investment spell. Note that each individual-stage hazard function displays positive duration dependence, indicating that at no time during the investment process do firms cross a threshold upon 
which FDI likelihood decreases. ${ }^{14}$ However, this desire for new investment is not uniform across location in the investment sequence. A Mantel-Cox log-rank test for hazard function equality reveals significant differences among hazard rates at each investment stage, indicating that investment likelihood increases over the firm's FDI sequence, as we expected.

\subsection{Cox Proportional Hazard Model}

Although the Kaplan-Meier results indicate differences in investment likelihood across individual investment stages, these results do not allow us to examine how firm-specific factors affect investment likelihood at each stage. For this purpose, we apply a Cox (1972) proportional hazard model. A semi-parametric partial likelihood model, the Cox model allows us to model the effects of the explanatory variables parametrically, while not requiring a parametric functional form for duration dependence. For this reason, as well as for the ability to include and update values for each time-varying covariate, the Cox model is preferred to fully parametric specifications.

The Cox model can be formulated as

$$
\lambda_{i}(t)=\lambda_{o}(t) \exp \left(\beta^{\prime} x_{i}(t)\right)
$$

where $x_{i}(t)$ represents a vector of the $i^{\text {th }}$ firm's covariates at time $t$, assumed to capture the effect of the firm-specific characteristics that influence investment likelihood. $\lambda_{o}(t)$ is the "baseline" hazard function (with unknown parametric form); it takes the interpretation as the hazard rate for the respective firm when all independent covariates are set to $0 . \lambda_{i}(t)$ is the proportion of $\lambda_{o}(t)$ determined by the effects of the firm-specific explanatory variables. We assume a multiplicative relationship between the covariates and the baseline hazard; in effect, each explanatory covariate affects the baseline hazard proportional to its effect on FDI likelihood. Firm-specific characteristics that positively influence investment are associated with higher investment hazards, which correspond to greater investment likelihood, whereas variables that negatively influence investment likelihood yield lower investment hazards. As we report our coefficient estimates via a

\footnotetext{
${ }^{14}$ In the FDI literature, Kaplan-Meier tests have often been used to examine the survivor function $S(t)$ of newly established firms, finding that survival rates decline as the firm ages. In contrast, we focus on the opposite case, or the likelihood of establishing a new firm, and thus produce a figure (Figure 1) opposite of that found in the firm survival literature.
} 
hazard ratio, ${ }^{15}$ variables that positively (negatively) affect investment produce hazard ratios greater than (less than) 1 .

Finally, as the Cox model is a continuous model while the investment data and explanatory variables are measured discretely, ties in spell duration length may occur. Breslow's (1974) approximation is employed to account for such occurrences.

The underlying assumption of the study is that initial investment spells begin in 1970. Initial firm- and macro-level characteristics are set to 1970 values, although they may be functions of prior values and may hence not truly be "initial." However, the initial conditions bias suggested by Heckman and Singer (1984) is avoided as strict restrictions on Japanese FDI in manufacturing existed prior to the Japanese government's 1969's five-stage deregulation of outward FDI controls (Mason, 1994). Therefore, the earliest most firms could establish foreign manufacturing affiliates was 1969, for which their 1970 firm-specific covariate values serve as good approximations.

\section{Estimation Results}

Estimation results (Tables 3-5) are provided to indicate how firm-specific characteristics affect both the likelihood of initial investment as well the likelihood of subsequent investment.

\subsection{Pooled Investment Estimation}

Table 3 provides estimates for the sample firms' pooled investment histories. While regressions based on pooled investment data are typically used to determine how firmspecific characteristics affect a firm's foreign investment, here they are provided only to compare the overall fit of the data in relation to previous studies. In Tables 4-5, the first three investment stages $\left(1^{\text {st }}, 2^{\text {nd }}\right.$, and $3^{\text {rd }}$ investment $)$ are examined separately to indicate how the firm's characteristics affect investment at each stage. For both the pooled and individual stage regressions, two separate specifications are examined: the first uses KeiretsuMember to differentiate between keiretsu and non-keiretsu members, while the second employs VerticalKeiretsuMember and HorizontalKeiretsuMember to distinguish

\footnotetext{
${ }^{15}$ Hazard ratios are determined as the exponentiated linear prediction, or $\exp (\mathrm{x} \beta)$.
} 
between non-keiretsu members and those who are members of vertically-oriented or horizontally-organized keiretsu.

Table 3 reveals several important results. Firm size has the predicted positive and significant influence on investment, regardless of whether we control for Size alone (column 1), or Size with TFP (columns 3-5). From the keiretsu-size interactive dummy variable (column 4), which measures size differentials between keiretsu members and non-members, the impact of size on investment appears similar regardless of keiretsu membership status.

\section{[Insert Table 3 here]}

We also find that a firm's Levinsohn-Petrin TFP measure positively and significantly affects its investment likelihood. In column (2) we include TFP without also controlling for firm size, while in columns (3) - (5) we control for both Size and TFP. In each case, both TFP and Size's influence on investment likelihood remain, even with the positive correlation between the two variables.

In regard to the other firm specific variables, the $H H I$ coefficient is significantly less than 1 across all specifications, indicating its negative relationship with investment likelihood. This suggests that a greater concentration in firm sales leads to less FDI possibly due to worries about cannibalization effects. A cannibalization effect may also be underlying the Diversification variable coefficient estimate, which reveals that a firm's future investment is more likely to come in an industry different than in previous investments.

Firms' $R \& D$ intensities and export ratios have a significant and positive affect on FDI. The hazard ratio for previous manufacturing experience (PrevManufInvst) is significantly greater than 1 , indicating that the number of previous manufacturing investments greatly increases the firm's future investment likelihood. Just as importantly, the coefficient on the PrevNonManufInvst is significantly less than 1, indicating that investment into wholesale/retail affiliates tends to push off investment into manufacturing. ${ }^{16}$

Keiretsu membership is shown in columns (1) - (4) to be a significant influence in the pooled investment sample, regardless of the firm size/productivity measures

\footnotetext{
${ }^{16}$ Note that while we also control for European GDP as a measure of demand, it is never a statistically significant investment influence.
} 
employed, suggesting that group members gain from at least one of the aforementioned keiretsu investment "benefits". As indicated in column (5), both horizontal and vertical keiretsu membership increases investment likelihood, with the marginal impact of vertical membership greater than that of horizontal membership. Finally, the firm's debt interest burden and cash flow had only slight impacts on the investment decision.

We conclude from Table 3 that the predictions of our model appear to match up well with the data. In cases where we expected positive influences on investment, the data support our conclusions. Where we had no a priori expectations, such as in the case of the firm's Hirschann-Herfindahl sales index, the results are consistent with the presence of a cannibalization effect. Moreover, using pooled data we are able to reproduce the literature's standard findings on how firm size, productivity and keiretsu membership affect FDI.

Of course, we did not select the hazard model to analyze pooled data, but rather because it allows us to examine individual investment steps. The results for the individual investment stages are presented next.

\subsection{Individual Spell Regressions}

Viewing each investment decision separately allows us to tell exactly when in the investment process the explanatory variables generate their influence. In a repeated spell specification firms' investment histories are partitioned by investment (first, second, third,...); we choose to focus on the first three individual stages, as they account for the complete investment history for $92 \%$ of our sample firms. Each stage is examined separately under the assumption of weak exogeneity between investment stages, so influences on the first investment can be viewed separately from those on subsequent investments. ${ }^{17}$

Separate analysis of each investment stage requires that the unobserved heterogeneity associated with previous stages be taken into account. Inclusion of variables that measure past history (PrevManufInvest, PrevNonManufInvest) in each regression satisfies this requirement. Table 4 displays the results of Cox regression analysis of the first investment stage, which indicates the stage at which the firm first

\footnotetext{
${ }^{17}$ See Ross (1996) for justification of this approach.
} 
becomes a manufacturing MNE in Europe, while Table 5 displays the estimation results for the second and third individual stage, which represent the firm's expansion of its European manufacturing network. Note that at each stage, PrevManufInvst drops out of the regression, as it is the same for all firms.

\section{[Insert Tables 4-5 about here]}

Combining the results from Tables 4-5, several of the strongly significant FDI influences from the pooled regression do not retain their significance at each individual investment stage. For instance, it appears that the "hurdle" of becoming a MNE is not associated with a firm's size as, in the first investment decision, Size is shown to be an insignificant influence on investment. It is only later, at the third investment stage, that firm size becomes an important investment determinant. This suggests that larger firms tend to have more investments than smaller firms, but are not more likely to become multinational firms. In contrast, TFP is shown to be a highly significant investment influence at each investment stage, including the first stage, indicating that productivity levels tend to increase investment likelihood throughout the investment sequence. Thus, while it is not the case that all firms have at least one investment (recall that in our dataset, only roughly two-thirds of the firms have manufacturing investments), these results suggest a high degree of Size and TFP heterogeneity among firms with at least one manufacturing investment. On the other hand, however, it appears that only the largest and most productive firms have larger manufacturing networks, and that smaller, less productive firms have not established such systems.

A firm's status with regard to keiretsu membership appears not to play a role in the decision to become a MNE. With keiretsu membership not a significant FDI influence at the first and second investment stages, but rather only a significant FDI determinant at the third investment stage, membership appears to have no role in the firm's initial investment decision. This would suggest that keiretsu members and nonmembers are equally likely to become MNEs, a result on the surface to contradict most previous empirical studies on the keiretsu-investment link. However, recall that most of these studies found the keiretsu-investment link using pooled investment data. This is exactly what we found in Table 3. However, by using the hazard model, this study is able to isolate the result that it appears that keiretsu members are simply more likely to have more investments. As a result, the keiretsu traits of informational exchanges, cross- 
ownership of stock, and eased capital market restrictions associated with firms' association with member banks, do not appear to have a significant effect on the decision to initially establish a manufacturing affiliate in Europe, but rather, membership appears to be mostly associated with increased investment totals. This indicates that the "credit channel" benefit of membership may not pertain to the ability to become a MNE, but rather the ability to expand holdings abroad. ${ }^{18}$

Similarly, a firm's $H H I$ index, while a significant investment deterrent in the pooled investment sample, does not affect a firm's initial or second investment decision. Much like Size and KeiretsuMember, HHI only plays a significant role for the firm's third investment. There $H H I$ has a negative effect. In contrast, Diversification affects all stages of the firm's investment sequence. Hence large firms with diversified product lines are the ones most likely to set up several affiliates abroad.

Similar to the TFP result, it appears that the hurdle of becoming a MNE may be better overcome by firms that are active in export markets and invest heavily in R\&D. Both a firm's export ratio (Exprt) and $R \& D$ intensity are strongly significant determinants of initial investment. In the case of $R \& D$, while it has a highly significant $(\mathrm{p}<0.01)$ affect on initial investment, its significance in impacting FDI declines at each investment stage, and by the firm's third stage, it no longer affects the investment decision.

We also find that previous investment into non-manufacturing, highly significant in the pooled investment regressions, significantly reduces the likelihood of initial investment, which suggests that firms choose to enter foreign markets through wholesale/retail affiliates as stepping stones to subsequent local production. However, once the firm has committed to producing abroad, the role of PrevNonManInvst diminishes as expected, and PrevNonManInvst does not impact subsequent investment decisions. Finally, the firm's financial health had little impact on the decision to become a MNE. InterestBurden and CashFlow only marginally affect the first and second-stage decisions, with none of the three variables impacting the third investment stage.

\footnotetext{
${ }^{18}$ Results not shown here also indicate vertical keiretsu members are more likely to have three investments as compared to horizontally affiliated members. We also find that, using a keiretsu-size interactive dummy variable, keiretsu firms with three investments were much smaller than non-members with similar investment totals, which suggests that member firms may indeed be following the group's main (and larger) firm abroad.
} 
Combining these results, we see that firm-specific influences change over the investment sequence, and while some variables' impacts are mostly felt during a firm's initial investment, others are felt at later investment stages. More importantly, these changes would not be recognized in a pooled investment history framework because, as we show in Table 3, each of these variables had a significant impact on the firm's pooled investment history. Interestingly, Size and TFP have different impacts on investment over the entire sequence, suggesting that it is productivity, and not asset holdings, that help firm's overcome the barrier to become a multinational firm.

\subsection{Robustness Check and Multiple-Investor Regressions}

We conduct several checks on the robustness of these results. First, in regressions not reported here, we replaced Size with parent employment levels (Employ), and found similar results. This is not surprising given the relatively high pairwise correlation between the two variables of 0.654 (Table 2). Next, we take the natural log of each of the firm-specific characteristics (excluding keiretsu membership) and perform similar regressions to those indicated in Tables 3. With one exception, our original results hold; the exception is in the $H H I$ index, which in most specifications now carried coefficients of around 0.642 , representing a much more highly significant negative influence on investment likelihood than in the previous specifications.

Finally, one may look at the regression results from the individual stages and wonder if our results are being generated by firms leaving the sample at each stage. That is, firms in the sample for the second investment stage regressions (Table 5, columns (1)(3)) have made one previous manufacturing investment, while firms in the "Third Investments" sample (Table 5, columns (4)-(6)) have established two previous manufacturing investments. As a result, firms with only one established manufacturing affiliate at the end of our sample are not included in the regression analysis of this stage.

Could it be that, by realizing a change in the sample firms as we proceed through the investment stages, we are biasing our results? To check this, we restrict the sample to those firms that establish at least 3 manufacturing investments, and re-run the Cox regressions at each investment stage. Our results, reported in Table 6 for the firms' 
pooled, first, and second investment stages, ${ }^{19}$ generally support our findings from our previous estimation that saw firms leave the sample at different investment decision stages. With this restricted sample, we find that keiretsu membership, firm size, and the HHI index all do not affect the firm's initial investment decision, even though in the pooled investment regressions they are found to be highly significant determinants. Similar to the full sample regressions, we see that TFP is significant for both the pooled sample as well as in each individual stage. We also find that previous non-manufacturing investments increase the time to first investment (decreased investment likelihood), while having no statistically significant impact on subsequent investments. Thus, it appears that our results are robust to the changing dataset as we move through the investment sequence, and the full sample results are not generated by firms simply leaving the sample as their investment sequence ends.

\section{[Insert Table 6 about here]}

Finally, concerns over multicollinearity typically arise when working with firmspecific data, especially in regard to firm size, TFP, and exports. Although Table 1 suggests low pair-wise correlation between these variables, and the inclusion of $T F P$ and Size does not affect each variable's coefficient estimates when included together in the regression analysis, we do wish to consider that there may be multicollinearity within the other group of firm specific variables. In Appendix Table 1, we sequentially add each firm specific variable into the model estimating the pooled investment data for the entire sample of firms. Analysis of these results suggests that there is no significant multicollinearity in our dataset.

\section{Conclusions}

This paper examined how firm-specific characteristics affect a firm's decision to establish an overseas affiliate and, thereafter, to expand its overseas operations. The use of a hazard model allowed us to analyze each individual investment stage separately. This revealed that the determinants of investment decisions change over the investment sequence. Specifically, we find that total factor productivity has a significant positive

\footnotetext{
${ }^{19}$ Third stage regression results are nearly identical to those found in Table 5, columns (4)-(6), since there are approximately the same number of firms in each sample; thus, we do not repeat these results here.
} 
impact on the likelihood of investment at each stage, whereas firm size and keiretsu membership only become significant for later investments. In other words, the more productive a firm is, the greater is the probability that it undertakes an investment, no matter whether this is the first or a subsequent investment. Larger firms and keiretsu members, however, are no more likely to undertake an initial investment than smaller firms or firms without keiretsu ties. They simply have more foreign affiliates on average. The opposite effect is observed with respect to a firm's R\&D intensity, export ratio, and previous non-manufacturing FDI: they only significantly affect the firm's initial investment.

Our conclusions, specifically with regard to firm size and keiretsu membership, are in stark contract to those in the existing literature. We showed that this is likely to come from the fact that previous studies have pooled the investment data and thereby ignored information that is important for understanding the FDI decision. In particular, these studies cannot distinguish between factors that determine a firm's investment total and those that affect the decision to set up an initial subsidiary. Strictly speaking, pooling the investment data is only justified if multinationals are single-product firms. But this is simply not the case in reality. By contrast, our approach and our results are fully consistent with a world in which multinationals are multi-product firms and where firm size is not only a function of productivity but also of the scope of the firm's product range. 


\section{Appendix I: Proofs}

Each period, firm $h$ chooses output to maximize $\sum_{i=1}^{n}\left(p_{i}(t)-c_{i j}-\lambda_{i j} s\right) x_{i}(t)$, where $p_{i}(t)$ is given by (1) and the indicator variable $\lambda_{i j}$ equals 1 if good $i$ is produced in country $h$ and zero if it is produced in country $f$. The corresponding first-order condition for a product $i$ is:

$$
a-2 \frac{b}{N(t)}\left(x_{i}(t)-d \sum_{j \neq i} x_{j}(t)\right)-\frac{b}{N(t)} e \sum_{l=1}^{m} y_{l}(t)-c_{i j}-\lambda_{i j} s=0 .
$$

Summing over all $n$ first-order conditions for firm $h$, and letting $X(t) \equiv \sum_{i=1}^{n} x_{i}(t)$ and $Y(t) \equiv \sum_{l=1}^{m} y_{i}(t)$, we have

$$
n a-\frac{2 b(1+d(n-1))}{N(t)} X(t)-\frac{b e n}{N(t)} Y(t)-\sum_{i=1}^{n}\left(c_{i j}+\lambda_{i j} s\right)=0
$$

Similarly, by adding up all the $m$ first-order conditions for the local firms in country $f$ we obtain

$$
m a-\frac{b e m}{N(t)} X(t)-\frac{b(m+1)}{N(t)} Y(t)-m w_{f}=0 .
$$

We can now solve (A.2) and (A.3) for the equilibrium values of $X(t)$ and $Y(t)$, and then use the following reformulation of (A.1) to derive firm $h$ 's output of product $i$

$$
x_{i}(t)=\frac{N(t)}{b(2-d)}\left(a-\frac{b d}{N(t)} X(t)-\frac{b e}{N(t)} Y(t)-c_{i j}-\lambda_{i j} s\right)=0 .
$$

It is straightforward to show that we can write $X(t)=[N(t) / b] X(\cdot)$ and $Y(t)=[N(t) / b] Y(\cdot)$, and therefore also $x_{i}(t)=[N(t) / b] x_{i}(\cdot)$, where $(\cdot)$ indicates dependence on the model's time-invariant parameters. Moreover, the contribution of good $i$ to firm $h$ 's profit (gross of sunk costs) turns out to be $\pi_{i}(t)=[N(t) / b]\left(x_{i}(\cdot)\right)^{2}$. The total gross profit of firm $h$ in period $t$ thus is $\Pi(t)=[N(t) / b] \sum_{i=1}^{n}\left(x_{i}(\cdot)\right)^{2}$. If $n$ is large and the contribution of each good to firm $h$ 's profit small, then the total profit is approximately $\Pi(t)=[N(t) / b](X(\cdot))^{2}$.

Now consider firm $h$ 's intertemporal investment problem. To determine the time $t_{l}$ at which the firm will undertake its first investment, we have to compare the present value of exporting all $n$ goods to the present value of producing one good locally and exporting the remaining $n-1$ goods. It is straightforward to establish that marginal changes in the time-invariant parameters that raise the Cournot equilibrium profit of producing one good locally and exporting the rest relative to the Cournot profit associated with exporting all goods imply an earlier $t_{l}$. Hence to establish our results we have to carry out comparative static exercises on (A.2) to (A.4).

Consider, for example, the effect of a marginal increase in firm $h$ 's productivity (assuming equal productivity in each good). Using (A.2) and (A.3), we note that this raises the firm's overall output $X(\cdot)$ and lowers the total output of the local firms $Y(\cdot)$. However, the output of firm $h$ rises by more, if it produces one good $i$ in country $f$, 
provided that $w_{f}<c_{i h}+s$. First, the lower variable cost associated with one FDI project implies a bigger gain in market share relative to the local firms. Second, the output of the good produced in $f$ rises relative to the output of the other goods produced by firm $h$ (see (A.4)), thus providing an additional efficiency gain. Hence an increase in productivity means that the firm will invest earlier. Similar comparative static effects can be derived for the other time-invariant parameters, including per-capita demand, wages, and industry concentration.

To prove the result concerning the cannibalization effect, we need to compare the change in profit from (i) moving from one affiliate to two affiliates with the change in profit from (ii) moving from zero to one affiliate. Subtracting the change in profit of (ii) from that of (i), we obtain.

$$
-\frac{2(d(1+m)-e) b t^{2}\left(4(1+m)(1-d)+2 m n\left(d-e^{2}\right)+n(3 d+d m+e)\right)}{(2-d)\left(2(1+m)(1-d+d n)-m n e^{2}\right)^{2}} .
$$

Note that for $1>d>e>0$ this expression is strictly negative, which gives the desired result.

\section{Appendix II: Data Description}

- Japanese FDI data was compiled from three separate volumes (1985, 1993, 1995) of Toyo Keizai Inc.'s Japanese Overseas Investment: A complete listing by firms and countries.

- A consistent determination of industry affiliation for the principal Japanese parent and the European affiliate requires the collection of each firm's primary 4-digit 1987 U.S. Standard Industry Classification (SIC) code for the year of initial investment. SIC codes for the Japanese parents were found in Dun and Bradstreet's Principal International Businesses, National Register's Directory of Corporate Affiliations, and other publicly available sources. Numerous publicly available European sources provided the affiliates' codes. Since some of the European affiliates are too small to gain entry into corporate listings, the main offices of most national foreign investment agencies (e.g. Invest in Denmark Agency, Invest in Finland Bureau, Hungarian Trade Commission) provided information on affiliates' main business lines. Main business lines reported in earlier SIC revisions $(1972,1977)$ or in the European NACE format were converted to the 1987 SIC equivalent by standard classification concordances.

- Firm-specific characteristics (size, R\&D, exports) are located in various issues of Toyo Keizai's Japan Company Handbook as well as the Pacific Basic Capital Markets (PACAP) database.

- Data for IndExp is located in the OECD's International Trade by Commodities Statistics CD-ROM. Standard classification concordances are used to convert the data to 4-digit SIC.

- Countries in the sample include: EU-15, plus Cyprus, Czech Republic, Hungary, Iceland, Norway, Poland, and Switzerland 


\section{References}

Baldwin, R.E, Ottaviano, G.I.P., 2001. Multiproduct multinationals and reciprocal FDI dumping. Journal of International Economics 54, 429-448.

Belderbos, R., Sleuwaegen, L., 1996. Japanese Firms and the Decision to Invest Abroad: Business Groups and Regional Core Networks. Review of Economics and Statistics 78, 214-220.

Blomström, M., Lipsey, R., 1991. Firm Size and Foreign Operations of Multinationals. Scandinavian Journal of Economics 93, 101-107.

Blonigen, B., Ellis, C., Fausten, D., 2005. Industrial Groupings and Foreign Direct Investment. Journal of International Economics 65, 75-91.

Breslow, N., 1974. Covariance analysis of censored survival data. Biometrics 30, 89-100.

Cameron, A.C., Trivedi, P., 1998. Regression analysis of count data. Cambridge University Press, Cambridge.

Chang, S.J., Rosenzweig, P., 2001. The choice of entry mode in sequential foreign direct investment. Strategic Management Journal 22, 747-776.

Cox, D., 1972. Regression Models and Life Tables. Journal of the Royal Statistical Society 34, 187-220.

Dixit, A. and R. Pindyck (1994), Investment under Uncertainty, Princeton University Press, Princeton, NJ.

Drake, T., Caves, R., 1992. Changing Determinants of Japanese Foreign Investment in the United States. Journal of the Japanese and International Economies 6, 228-246.

Girma, S., Görg, H., and Strobl, E. (2004). Exports, international investment, and plant performance: evidence from a non-parametric test. Economic Letters 83, 317-324.

Greenaway, D.,Kneller, R., 2005. Firm Heterogeneity, Exporting and Foreign Direct Investment: A Survey. Mimeo, University of Nottingham.

Head, K., Ries, J., 2003. Heterogeneity and the FDI versus export decision of Japanese manufacturers. Journal of the Japanese and International Economies 17, 448-467.

Head, K., Ries, J., Swenson, D., 1999. Attracting foreign manufacturing: Investment promotion and agglomeration. Regional Science and Urban Economics 29, 197-218.

Heckman, J., Singer, B., 1984. Econometric Duration Analysis. Journal of Econometrics $24,63-132$. 
Helpman, E., Melitz, M., Yeaple, S., 2004. Export versus FDI. American Economic Review, 94, 300-317.

Hennart, J-F, 1991. The Transaction Costs Theory of Joint Ventures: An Empirical Study of Japanese Subsidiaries in the United States. Management Science 37, 483-497.

Horst, T., 1972. Firm and Industry Determinants of the Decision to Invest Abroad: An Empirical Study. Review of Economics and Statistics. 54, 256-266.

Horstmann, I., Markusen, J., 1987. Strategic investments and the development of multinationals. International Economic Review 28, 109-121.

Hymer, S., 1960. The international operations of national firms: A study of direct foreign investment. MIT Press, Cambridge.

Kiefer, N., 1988. Economic Duration Data and Hazard Functions. Journal of Economic Literature 26, 646-679.

Levinsohn, J. and Petrin, A., 2003. Estimating Production Functions Using Inputs to Control for Unobservables Review of Economic Studies v70, n2: 317-41.

Lindbeck, A., Snower D., 2003. The firm as a pool of factor complementarities. University of Kiel, mimeo.

Markusen, J. 2002. Multinational Firms and the Theory of International Trade. MIT Press, Cambridge.

Mason, M., 1994. Historical Perspectives on Japanese Direct Investment in Europe, in: Mason, M., Encarnation, D. (Eds.), Does Ownership Matter?: Japanese Multinationals in Europe. Clarendon Press, Oxford.

Padmanabhan, P., Cho, K.R., 1996. Ownership Strategy for a Foreign Firm: An Empirical Investigation of Japanese Firms. Management International Review 36, 45-65.

Raff, H., Ryan, M., and F. Staehler, 2005. Firm Productivity and the Foreign-Market Entry Decision. CESIfo Working Paper \#1676.

Rob, R., Vettas N., 2003. Foreign direct investment and exports with growing demand. Review of Economic Studies 70, 629-648.

Ross, S., 1996. Stochastic Processes. $2^{\text {nd }}$ edition. John Wiley, New York.

Swedenborg, B., 1979. The Multinational Operations of Swedish Firms: An Analysis of Determinants and Effects, IUI, Stockholm. 
Trevino, L., Daniels, J., 1994. An Empirical Assessment of the Preconditions of Japanese Manufacturing Foreign Direct Investment in the United States. Weltwirtschaftliches Archiv 130, 576-599.

UNCTAD (2004), World Investment Report 2004, United Nations, New York. 
Table 3: Firm-Specific Investment Determinants for Pooled Investment Histories: All Firms

\begin{tabular}{|c|c|c|c|c|c|c|}
\hline & $(1)$ & $(2)$ & (3) & (4) & $(5)$ & (6) \\
\hline \multicolumn{7}{|l|}{ Firm Size/Productivity } \\
\hline Size & $1.101^{\mathrm{a}}$ & & $1.101^{\mathrm{b}}$ & $1.001^{b}$ & $1.101^{\mathrm{a}}$ & $1.101^{\mathrm{a}}$ \\
\hline KeiretsuMember*Size & 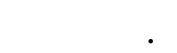 & & & 0.989 & & \\
\hline TFP & . & $1.131^{\mathrm{a}}$ & $1.131^{b}$ & $1.131^{\mathrm{b}}$ & $1.128^{b}$ & $1.098^{b}$ \\
\hline KeiretsuMember*TFP & . & & & $1.059^{\mathrm{a}}$ & . & \\
\hline \multicolumn{7}{|l|}{ Other Firm Characteristics } \\
\hline HHI & $0.943^{\mathrm{a}}$ & $\mathbf{0 . 9 5 3}^{\mathrm{b}}$ & $0.978^{b}$ & $0.962^{\mathrm{a}}$ & $0.963^{\mathrm{a}}$ & $0.961^{\mathrm{a}}$ \\
\hline Diversification & $1.271^{\mathrm{a}}$ & $1.281^{\mathrm{a}}$ & $1.281^{\mathrm{a}}$ & $1.297^{\mathrm{a}}$ & $1.285^{\mathrm{a}}$ & $1.283^{\mathrm{a}}$ \\
\hline Export Ratio (Exprt) & $1.007^{b}$ & $1.005^{b}$ & $1.006^{c}$ & $1.005^{c}$ & $1.005^{c}$ & $1.005^{c}$ \\
\hline R\&D Expenditure $(R \& D)$ & $1.092^{\mathrm{a}}$ & $1.098^{\mathrm{a}}$ & $1.090^{\mathrm{a}}$ & $1.090^{\mathrm{a}}$ & $1.089^{a}$ & $1.088^{\mathrm{a}}$ \\
\hline PrevManufInvst & $1.169^{a}$ & $1.177^{\mathrm{a}}$ & $1.107^{b}$ & $1.106^{b}$ & $1.106^{b}$ & $1.105^{b}$ \\
\hline PrevNonManufInvst & 0.958 & $0.966^{c}$ & $0.956^{c}$ & $0.956^{c}$ & $0.956^{c}$ & $0.957^{\mathrm{c}}$ \\
\hline \multicolumn{7}{|l|}{ Keiretsu Membership } \\
\hline KeiretsuMember & $1.307^{b}$ & $1.234^{\mathrm{c}}$ & $1.119^{c}$ & $1.236^{\mathrm{c}}$ & & $1.232^{\mathrm{c}}$ \\
\hline VerticalKeiretsuMember & . & & & . & $1.177^{\mathrm{c}}$ & . \\
\hline HorizontalKeiretsuMember & . & & . & . & $1.121^{c}$ & - \\
\hline \multicolumn{7}{|l|}{ Financial Data } \\
\hline Gross Revenue & . & . & . & . & . & 1.047 \\
\hline Interest Burden & . & . & . & . & . & $0.963^{c}$ \\
\hline Cash Flow & - & - & - & - & . & $1.029^{c}$ \\
\hline Industry Membership Dummy & Yes & Yes & Yes & Yes & Yes & Yes \\
\hline Year Dummy & Yes & Yes & Yes & Yes & Yes & Yes \\
\hline Number of Observations & 5880 & 5880 & 5880 & 5880 & 5880 & 5880 \\
\hline Log-Likelihood & -1480.83 & -1384.53 & -1380.12 & -1382.62 & -1383.72 & -1372.27 \\
\hline Wald Test & 138.84 & 138.44 & 140.15 & 147.97 & 148.01 & 156.10 \\
\hline$\chi^{2}$ test & 0.000 & 0.000 & 0.000 & 0.000 & 0.000 & 0.000 \\
\hline
\end{tabular}


Table 4: Firm-Specific Investment Determinants for First Investments: All Firms

\begin{tabular}{|c|c|c|c|c|c|c|c|c|}
\hline & $(1)$ & $(2)$ & $(3)$ & (4) & (5) & $(6)$ & (7) & (8) \\
\hline \multicolumn{9}{|l|}{ Firm Size/Productivity } \\
\hline Size & 1.000 & - & 1.000 & - & 1.000 & 1.000 & 1.000 & 1.000 \\
\hline KeiretsuMember*Size & • & & & & & 0.999 & & \\
\hline TFP & . & $1.103^{b}$ & . & $1.102^{b}$ & $1.101^{b}$ & $1.101^{b}$ & $1.101^{b}$ & $1.101^{b}$ \\
\hline KeiretsuMember*TFP & • & . & - & • & • & $1.042^{b}$ & • & \\
\hline \multicolumn{9}{|l|}{ Other Firm Characteristics } \\
\hline HHI & . & . & 0.999 & 0.997 & 0.996 & 0.997 & 0.997 & 0.996 \\
\hline Diversification & . & . & $1.147^{\mathrm{a}}$ & $1.159^{\mathrm{a}}$ & $1.148^{\mathrm{a}}$ & $1.151^{\mathrm{a}}$ & $1.147^{\mathrm{a}}$ & $1.161^{\mathrm{a}}$ \\
\hline Export Ratio (Exprt) & . & . & $1.010^{c}$ & $1.010^{c}$ & $1.009^{c}$ & $1.009^{c}$ & $1.009^{c}$ & $1.010^{c}$ \\
\hline $\mathrm{R} \& \mathrm{D}$ Expenditure $(R \& D)$ & . & . & $1.137^{\mathrm{a}}$ & $1.131^{\mathrm{a}}$ & $1.133^{\mathrm{a}}$ & $1.134^{\mathrm{a}}$ & $1.133^{\mathrm{a}}$ & $1.131^{\mathrm{a}}$ \\
\hline PrevNonManufInvst & • & . & $0.786^{\mathrm{a}}$ & $0.800^{\mathrm{a}}$ & $0.794^{\mathrm{a}}$ & $0.787^{\mathrm{a}}$ & $0.790^{\mathrm{a}}$ & $0.842^{\mathrm{a}}$ \\
\hline \multicolumn{9}{|l|}{ Keiretsu Membership } \\
\hline KeiretsuMember & . & . & 1.010 & 1.065 & 1.091 & 1.099 & . & 1.074 \\
\hline VerticalKeiretsuMember & . & . & • & • & • & • & 1.101 & \\
\hline HorizontalKeiretsuMember & - & - & • & • & • & - & 1.121 & \\
\hline \multicolumn{9}{|l|}{ Financial Data } \\
\hline Gross Revenue & . & . & . & . & . & . & . & 1.026 \\
\hline Interest Burden & • & . & . & . & . & . & . & $0.972^{c}$ \\
\hline Cash Flow & • & . & - & • & • & - & • & $1.067^{c}$ \\
\hline Industry Membership Dum & Yes & Yes & Yes & Yes & Yes & Yes & Yes & Yes \\
\hline Year Dummy & Yes & Yes & Yes & Yes & Yes & Yes & Yes & Yes \\
\hline Number of Observations & 4698 & 4698 & 4698 & 4698 & 4698 & 4698 & 4698 & 4698 \\
\hline Log-Likelihood & -651.83 & -617.25 & -631.72 & -604.44 & -597.36 & -596.48 & -597.96 & -592.37 \\
\hline Wald Test & 31.45 & 34.20 & 91.54 & 93.31 & 94.13 & 94.16 & 94.18 & 95.87 \\
\hline$\chi^{2}$ test & 0.048 & 0.025 & 0.000 & 0.000 & 0.000 & 0.000 & 0.000 & 0.000 \\
\hline
\end{tabular}


Table 5: Firm-Specific Investment Determinants for Second and Third Investments: All Firms

\begin{tabular}{|c|c|c|c|c|c|c|c|c|}
\hline & \multicolumn{4}{|c|}{ Second Investment } & \multicolumn{4}{|c|}{ Third Investment } \\
\hline & (1) & (2) & (3) & (4) & (5) & $(6)$ & $(7)$ & (8) \\
\hline Firm Size/ Productivity & & & & & & & & \\
\hline Size & 1.001 & & 1.001 & 1.001 & $1.050^{b}$ & & $1.050^{b}$ & $1.051^{b}$ \\
\hline TFP & & $1.070^{b}$ & $1.065^{b}$ & $1.065^{b}$ & • & $1.097^{\mathrm{c}}$ & $1.099^{c}$ & $1.097^{\mathrm{c}}$ \\
\hline Other Firm Characteristi & & & & & & & & \\
\hline HHI & 1.000 & 1.000 & 1.000 & 0.999 & $0.945^{\mathrm{a}}$ & $0.955^{\mathrm{a}}$ & $\mathbf{0 . 9 5 3}^{\mathrm{a}}$ & $0.953^{\mathrm{a}}$ \\
\hline Diversification & $1.188^{\mathrm{a}}$ & $1.189^{\mathrm{a}}$ & $1.210^{\mathrm{a}}$ & $1.211^{\mathrm{a}}$ & $1.242^{\mathrm{a}}$ & $1.245^{\mathrm{a}}$ & $1.251^{\mathrm{a}}$ & $1.251^{\mathrm{a}}$ \\
\hline Export Ratio (Exprt) & $1.040^{c}$ & $1.050^{c}$ & $1.040^{c}$ & $1.038^{c}$ & $1.022^{b}$ & $1.015^{b}$ & $1.017^{b}$ & $1.017^{b}$ \\
\hline R\&D Expenditures & $1.108^{b}$ & $1.138^{b}$ & $1.124^{b}$ & $1.125^{b}$ & 0.942 & 0.980 & 0.963 & 0.961 \\
\hline PrevNonManufInvst & 0.955 & 0.947 & 0.956 & 0.952 & 1.010 & 1.049 & 1.039 & 1.041 \\
\hline PrevDurationLength & $0.971^{\mathrm{a}}$ & $0.971^{\mathrm{a}}$ & $0.976^{\mathrm{a}}$ & $0.977^{\mathrm{a}}$ & 0.922 & 0.926 & 0.930 & 0.930 \\
\hline Keiretsu Membership & & & & & & & & \\
\hline Keiretsu Membership & 1.090 & 1.107 & 1.090 & 1.090 & $1.389^{c}$ & $1.440^{c}$ & $1.389^{c}$ & $1.389^{c}$ \\
\hline Financial Data & & & & & & & & \\
\hline Gross Revenue & . & . & . & 1.021 & . & . & . & 1.019 \\
\hline Interest Burden & . & . & . & $0.974^{c}$ & . & . & . & 0.981 \\
\hline Cash Flow & . & - & - & 1.054 & . & - & . & 1.047 \\
\hline Industry Member Dummy & Yes & Yes & Yes & Yes & Yes & Yes & Yes & Yes \\
\hline Year Dummy & Yes & Yes & Yes & Yes & Yes & Yes & Yes & Yes \\
\hline Number of Observations & 3239 & 3239 & 3239 & 3239 & 1906 & 1906 & 1906 & 1906 \\
\hline Log-Likelihood & -207.58 & -199.97 & -196.76 & -195.89 & -88.93 & -85.79 & -82.09 & -81.17 \\
\hline Wald Test & 80.89 & 82.65 & 84.67 & 85.29 & 45.67 & 46.78 & 46.99 & 47.34 \\
\hline$\chi^{2}$ test & 0.000 & 0.000 & 0.000 & 0.000 & 0.000 & 0.000 & 0.000 & 0.000 \\
\hline
\end{tabular}

Coefficients expressed as hazard ratios. Significance Levels: ${ }^{a}-\mathrm{p}<0.01,{ }^{\mathrm{b}}-\mathrm{p}<0.05,{ }^{\mathrm{c}}-\mathrm{p}<0.10$ 
Table 6: Firm-Specific Investment Determinants for Multiple Investors Only

\begin{tabular}{|c|c|c|c|c|c|c|c|c|c|}
\hline & \multicolumn{3}{|c|}{ All (Pooled) Investments } & \multicolumn{3}{|c|}{ First Investments } & \multicolumn{3}{|c|}{ Second Investment } \\
\hline & (1) & (2) & (3) & (4) & (5) & (6) & (7) & (8) & (9) \\
\hline \multicolumn{10}{|l|}{ Firm Size/Productivity } \\
\hline Size & $1.101^{b}$ & & $1.100^{b}$ & 1.000 & & 1.000 & 1.000 & • & 1.001 \\
\hline TFP & . & $1.098^{b}$ & $1.097^{b}$ & . & $1.141^{\mathrm{c}}$ & $1.139^{c}$ & . & $1.053^{\mathrm{c}}$ & 1.051 \\
\hline \multicolumn{10}{|l|}{ Other Firm Characteristics } \\
\hline $\mathrm{HHI}$ & $0.945^{b}$ & $0.952^{b}$ & $0.957^{b}$ & 0.999 & 0.999 & 0.999 & 0.999 & 0.999 & 0.999 \\
\hline Diversification & $1.171^{\mathrm{a}}$ & $1.184^{\mathrm{a}}$ & $1.185^{\mathrm{a}}$ & $1.117^{\mathrm{a}}$ & $1.196^{b}$ & $1.197^{\mathrm{a}}$ & $1.156^{\mathrm{a}}$ & $1.169^{b}$ & $1.177^{\circ}$ \\
\hline Export Ratio (Exprt) & $1.006^{b}$ & $1.009^{b}$ & $1.008^{b}$ & $1.007^{\mathrm{a}}$ & $1.008^{\mathrm{a}}$ & $1.009^{\mathrm{a}}$ & $1.006^{b}$ & $1.011^{b}$ & $1.011^{\mathrm{b}}$ \\
\hline R\&D Expenditure $(R \& D)$ & $1.107^{\mathrm{a}}$ & $1.109^{a}$ & $1.097^{\mathrm{a}}$ & $1.005^{b}$ & $1.009^{b}$ & $1.110^{b}$ & $1.076^{\mathrm{c}}$ & $1.074^{\mathrm{c}}$ & 1.074 \\
\hline PrevManufInvst & $1.080^{b}$ & $1.088^{b}$ & $1.088^{b}$ & & & & . & . & . \\
\hline PrevNonManufInvst & $0.957^{b}$ & $0.968^{b}$ & $0.962^{b}$ & $0.946^{b}$ & $0.9510^{b}$ & $0.921^{b}$ & 0.999 & 0.997 & 0.978 \\
\hline PrevDuration & . & . & . & . & . & . & $0.973^{a}$ & $0.972^{\mathrm{a}}$ & $0.974^{a}$ \\
\hline $\begin{array}{l}\text { KeiretsuMembership } \\
\text { KeiretsuMember }\end{array}$ & $1.1966^{b}$ & $1.186^{b}$ & $1.189^{b}$ & 1.054 & 1.040 & 1.051 & 1.096 & 1.096 & 1.095 \\
\hline \multicolumn{10}{|l|}{ Financial Data } \\
\hline Gross Revenue & - & - & 1.043 & - & - & 1.106 & . & . & 1.020 \\
\hline Interest Burden & . & . & $0.962^{c}$ & . & . & $0.984^{c}$ & . & . & 0.973 \\
\hline Cash Flow & - & - & $1.024^{c}$ & - & - & $1.061^{\mathrm{c}}$ & • & - & 1.057 \\
\hline Industry Member Dummy & Yes & Yes & Yes & Yes & Yes & Yes & Yes & Yes & Yes \\
\hline Year Dummy & Yes & Yes & Yes & Yes & Yes & Yes & Yes & Yes & Yes \\
\hline Log-Likelihood & -805.67 & -779.65 & -771.85 & -242.56 & -225.24 & -221.15 & -167.77 & -161.29 & -163.24 \\
\hline Wald Test & 88.03 & 92.03 & 96.94 & 90.16 & 93.92 & 94.67 & 87.56 & 91.56 & 92.49 \\
\hline$\chi^{2}$ test & 0.000 & 0.000 & 0.000 & 0.000 & 0.000 & 0.000 & 0.000 & 0.000 & 0.000 \\
\hline
\end{tabular}


Figure 1. Kaplan-Meier Integrated Hazard Estimates of Individual Investment Stages

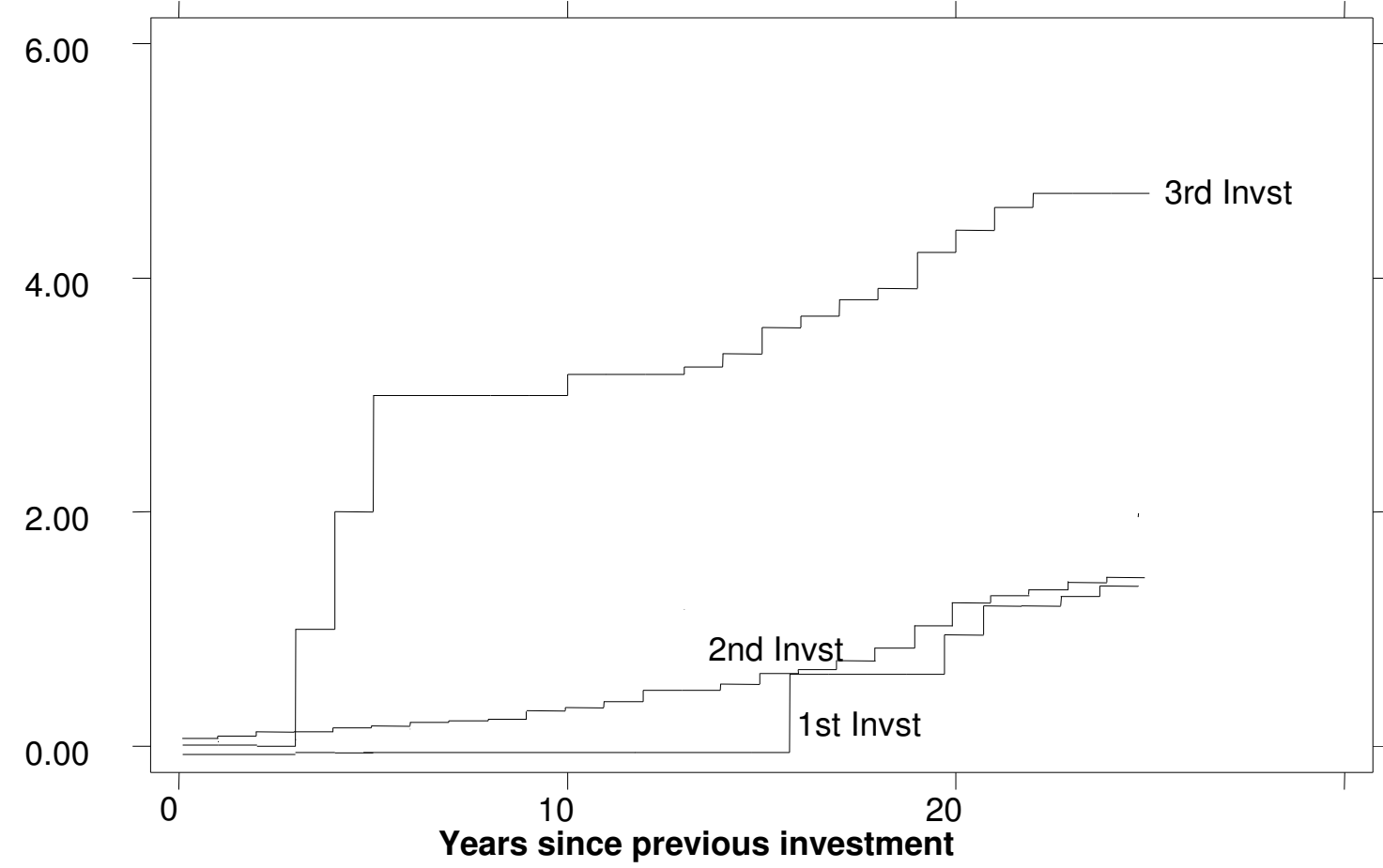


Appendix Table 1. Additional Regression Table for Pooled Investment History: All Firms

\begin{tabular}{|c|c|c|c|c|c|c|c|c|c|c|}
\hline & $(1)$ & $(2)$ & $(3)$ & $(4)$ & $(5)$ & (6) & $(7)$ & $(8)$ & $(9)$ & $(10)$ \\
\hline Size & $1.101^{\mathrm{a}}$ & & $1.101^{\mathrm{a}}$ & $1.097^{\mathrm{a}}$ & $1.095^{\mathrm{a}}$ & $1.093^{\mathrm{a}}$ & $1.093^{\mathrm{a}}$ & $1.092^{\mathrm{a}}$ & $1.092^{\mathrm{a}}$ & $1.091^{\mathrm{a}}$ \\
\hline TFP & & $1.141^{\mathrm{a}}$ & $1.139^{a}$ & $1.139^{a}$ & $1.137^{\mathrm{a}}$ & $1.136^{\mathrm{a}}$ & $1.136^{\mathrm{a}}$ & $1.136^{\mathrm{a}}$ & $1.132^{\mathrm{a}}$ & $1.132^{\mathrm{a}}$ \\
\hline Keiretsu Membership & & & & $1.321^{b}$ & $1.322^{b}$ & $1.314^{b}$ & $1.299^{b}$ & $1.274^{\mathrm{b}}$ & $1.269^{b}$ & $1.257^{\mathrm{b}}$ \\
\hline HHI & & & & & $0.963^{b}$ & $0.953^{b}$ & $0.953^{b}$ & $0.952^{b}$ & $0.948^{b}$ & $0.945^{b}$ \\
\hline Export Ratio & & & & & & $1.082^{b}$ & $\mathbf{1 . 0 8 3}^{\mathrm{b}}$ & $1.079^{b}$ & $1.077^{b}$ & $1.076^{b}$ \\
\hline $\mathrm{R} \& \mathrm{D}$ & & & & & & & $1.098^{\mathrm{a}}$ & $1.090^{\mathrm{a}}$ & $1.090^{\mathrm{a}}$ & $1.090^{\mathrm{a}}$ \\
\hline PrevManuf & & & & & & & & $1.167^{\mathrm{a}}$ & $1.137^{\mathrm{a}}$ & $1.123^{\mathrm{a}}$ \\
\hline PrevNonManuf & & & & & & & & & $0.956^{c}$ & $0.956^{c}$ \\
\hline Diversification & & & & & & & & & & $1.281^{\mathrm{a}}$ \\
\hline Number of Obs. & 5880 & 5880 & 5880 & 5880 & 5880 & 5880 & 5880 & 5880 & 5880 & 5880 \\
\hline Log-Likelihood & -1529.49 & -1431.59 & -1421.30 & -1418.64 & -1415.11 & -1413.55 & -1407.66 & -1403.52 & -1400.87 & -1380.12 \\
\hline Wald Test & 11.21 & 11.22 & 60.41 & 60.97 & 96.92 & 100.08 & 114.90 & 129.73 & 130.15 & 140.15 \\
\hline$\chi^{2}$ test & 0.047 & 0.047 & 0.000 & 0.000 & 0.000 & 0.000 & 0.000 & 0.000 & 0.000 & 0.000 \\
\hline
\end{tabular}

Coefficients expressed as hazard ratios. Significance Levels: $a-p<0.01$, $*_{*}-\mathrm{p}<0.05, *_{-} \mathrm{p}<0.10$ 



\section{CESifo Working Paper Series}

(for full list see www.cesifo-group.de)

1812 Robert S. Chirinko and Hisham Foad, Noise vs. News in Equity Returns, September 2006

1813 Oliver Huelsewig, Eric Mayer and Timo Wollmershaeuser, Bank Behavior and the Cost Channel of Monetary Transmission, September 2006

1814 Michael S. Michael, Are Migration Policies that Induce Skilled (Unskilled) Migration Beneficial (Harmful) for the Host Country?, September 2006

1815 Eytan Sheshinski, Optimum Commodity Taxation in Pooling Equilibria, October 2006

1816 Gottfried Haber and Reinhard Neck, Sustainability of Austrian Public Debt: A Political Economy Perspective, October 2006

1817 Thiess Buettner, Michael Overesch, Ulrich Schreiber and Georg Wamser, The Impact of Thin-Capitalization Rules on Multinationals' Financing and Investment Decisions, October 2006

1818 Eric O’N. Fisher and Sharon L. May, Relativity in Trade Theory: Towards a Solution to the Mystery of Missing Trade, October 2006

1819 Junichi Minagawa and Thorsten Upmann, Labor Supply and the Demand for Child Care: An Intertemporal Approach, October 2006

1820 Jan K. Brueckner and Raquel Girvin, Airport Noise Regulation, Airline Service Quality, and Social Welfare, October 2006

1821 Sijbren Cnossen, Alcohol Taxation and Regulation in the European Union, October 2006

1822 Frederick van der Ploeg, Sustainable Social Spending in a Greying Economy with Stagnant Public Services: Baumol’s Cost Disease Revisited, October 2006

1823 Steven Brakman, Harry Garretsen and Charles van Marrewijk, Cross-Border Mergers \& Acquisitions: The Facts as a Guide for International Economics, October 2006

1824 J. Atsu Amegashie, A Psychological Game with Interdependent Preference Types, October 2006

1825 Kurt R. Brekke, Ingrid Koenigbauer and Odd Rune Straume, Reference Pricing of Pharmaceuticals, October 2006

1826 Sean Holly, M. Hashem Pesaran and Takashi Yamagata, A Spatio-Temporal Model of House Prices in the US, October 2006 
1827 Margarita Katsimi and Thomas Moutos, Inequality and the US Import Demand Function, October 2006

1828 Eytan Sheshinski, Longevity and Aggregate Savings, October 2006

1829 Momi Dahan and Udi Nisan, Low Take-up Rates: The Role of Information, October 2006

1830 Dieter Urban, Multilateral Investment Agreement in a Political Equilibrium, October 2006

1831 Jan Bouckaert and Hans Degryse, Opt In Versus Opt Out: A Free-Entry Analysis of Privacy Policies, October 2006

1832 Wolfram F. Richter, Taxing Human Capital Efficiently: The Double Dividend of Taxing Non-qualified Labour more Heavily than Qualified Labour, October 2006

1833 Alberto Chong and Mark Gradstein, Who's Afraid of Foreign Aid? The Donors' Perspective, October 2006

1834 Dirk Schindler, Optimal Income Taxation with a Risky Asset - The Triple Income Tax, October 2006

1835 Andy Snell and Jonathan P. Thomas, Labour Contracts, Equal Treatment and WageUnemployment Dynamics, October 2006

1836 Peter Backé and Cezary Wójcik, Catching-up and Credit Booms in Central and Eastern European EU Member States and Acceding Countries: An Interpretation within the New Neoclassical Synthesis Framework, October 2006

1837 Lars P. Feld, Justina A.V. Fischer and Gebhard Kirchgaessner, The Effect of Direct Democracy on Income Redistribution: Evidence for Switzerland, October 2006

1838 Michael Rauscher, Voluntary Emission Reductions, Social Rewards, and Environmental Policy, November 2006

1839 Vincent Vicard, Trade, Conflicts, and Political Integration: the Regional Interplays, November 2006

1840 Erkki Koskela and Mikko Puhakka, Stability and Dynamics in an Overlapping Generations Economy under Flexible Wage Negotiation and Capital Accumulation, November 2006

1841 Thiess Buettner, Michael Overesch, Ulrich Schreiber and Georg Wamser, Taxation and Capital Structure Choice - Evidence from a Panel of German Multinationals, November 2006

1842 Guglielmo Maria Caporale and Alexandros Kontonikas, The Euro and Inflation Uncertainty in the European Monetary Union, November 2006 
1843 Jan K. Brueckner and Ann G. Largey, Social Interaction and Urban Sprawl, November 2006

1844 Eytan Sheshinski, Differentiated Annuities in a Pooling Equilibrium, November 2006

1845 Marc Suhrcke and Dieter Urban, Are Cardiovascular Diseases Bad for Economic Growth?, November 2006

1846 Sam Bucovetsky and Andreas Haufler, Preferential Tax Regimes with Asymmetric Countries, November 2006

1847 Luca Anderlini, Leonardo Felli and Andrew Postlewaite, Should Courts always Enforce what Contracting Parties Write?, November 2006

1848 Katharina Sailer, Searching the eBay Marketplace, November 2006

1849 Paul De Grauwe and Pablo Rovira Kaltwasser, A Behavioral Finance Model of the Exchange Rate with Many Forecasting Rules, November 2006

1850 Doina Maria Radulescu and Michael Stimmelmayr, ACE vs. CBIT: Which is Better for Investment and Welfare?, November 2006

1851 Guglielmo Maria Caporale and Mario Cerrato, Black Market and Official Exchange Rates: Long-Run Equilibrium and Short-Run Dynamics, November 2006

1852 Luca Anderlini, Leonardo Felli and Andrew Postlewaite, Active Courts and Menu Contracts, November 2006

1853 Andreas Haufler, Alexander Klemm and Guttorm Schjelderup, Economic Integration and Redistributive Taxation: A Simple Model with Ambiguous Results, November 2006

1854 S. Brock Blomberg, Thomas DeLeire and Gregory D. Hess, The (After) Life-Cycle Theory of Religious Contributions, November 2006

1855 Albert Solé-Ollé and Pilar Sorribas-Navarro, The Effects of Partisan Alignment on the Allocation of Intergovernmental Transfers. Differences-in-Differences Estimates for Spain, November 2006

1856 Biswa N. Bhattacharyay, Understanding the Latest Wave and Future Shape of Regional Trade and Cooperation Agreements in Asia, November 2006

1857 Matz Dahlberg, Eva Mörk, Jørn Rattsø and Hanna Ågren, Using a Discontinuous Grant to Identify the Effect of Grants on Local Taxes and Spending, November 2006

1858 Ernesto Crivelli and Klaas Staal, Size and Soft Budget Constraints, November 2006

1859 Jens Brøchner, Jesper Jensen, Patrik Svensson and Peter Birch Sørensen, The Dilemmas of Tax Coordination in the Enlarged European Union, November 2006 
1860 Marcel Gérard, Reforming the Taxation of Multijurisdictional Enterprises in Europe, “Coopetition” in a Bottom-up Federation, November 2006

1861 Frank Blasch and Alfons J. Weichenrieder, When Taxation Changes the Course of the Year - Fiscal Year Adjustments and the German Tax Reform 2000/2001, November 2006

1862 Hans Jarle Kind, Tore Nilssen and Lars Sørgard, Competition for Viewers and Advertisers in a TV Oligopoly, November 2006

1863 Bart Cockx, Stéphane Robin and Christian Goebel, Income Support Policies for PartTime Workers: A Stepping-Stone to Regular Jobs? An Application to Young LongTerm Unemployed Women in Belgium, December 2006

1864 Sascha O. Becker and Marc-Andreas Muendler, The Effect of FDI on Job Separation, December 2006

1865 Christos Kotsogiannis and Robert Schwager, Fiscal Equalization and Yardstick Competition, December 2006

1866 Mikael Carlsson, Stefan Eriksson and Nils Gottfries, Testing Theories of Job Creation: Does Supply Create Its Own Demand?, December 2006

1867 Jacques H. Drèze, Charles Figuières and Jean Hindriks, Voluntary Matching Grants Can Forestall Social Dumping, December 2006

1868 Thomas Eichner and Marco Runkel, Corporate Income Taxation of Multinationals and Unemployment, December 2006

1869 Balázs Égert, Central Bank Interventions, Communication and Interest Rate Policy in Emerging European Economies, December 2006

1870 John Geweke, Joel Horowitz and M. Hashem Pesaran, Econometrics: A Bird's Eye View, December 2006

1871 Hans Jarle Kind, Marko Koethenbuerger and Guttorm Schjelderup, Taxation in TwoSided Markets, December 2006

1872 Hans Gersbach and Bernhard Pachl, Cake Division by Majority Decision, December 2006

1873 Gunther Schnabl, The Evolution of the East Asian Currency Baskets - Still Undisclosed and Changing, December 2006

1874 Horst Raff and Michael J. Ryan, Firm-Specific Characteristics and the Timing of Foreign Direct Investment Projects, December 2006 